\title{
JUVENILE DETENTION: THE HIDDEN CLOSETS REVISITED*
}

\author{
IRA M. SCHWARTZ \\ University of Minnesots \\ GIDEON FISHMAN \\ University of Haifa, Israel
}

\author{
RADENE RAWSON HATFIELD \\ University of Minnesota
}

\author{
BARRY A. KRISBERG \\ National Council on Crime and Delinquency
}

\author{
ZVI EISIKOVITS \\ University of Haifa, Israel
}

\begin{abstract}
This is the first national study of juvenile detention in more than a decade. The findings indicate that these facilities are undergoing a fundamental and substantial change. The consensus of professional opinion as well as recommendations from national standard-setting bodies indicate that juvenile detention centers should be reserved for those youth who present a clear and substantial threat to the community and who need to be confined until they appear in court. Now these facilities are assuming an added function by serving as short-term commitment options for juvenile court judges. In addition, the study found that the excessive use of detention continues to be a major problem.
\end{abstract}

Detention does not deserve to be a major part in the juvenile justice process. It should be brief, terribly selective, and modest in its aims. If the rest of the system behaves, it should almost disappear ... detention should not be, as

* Funding for this research was provided by the Annie E. Casey Foundation, the Blandin Foundation, and the Northwest Area Foundation. The Humphrey Institute of the University of Minnesota and the National Council on Crime and Delinquency are hospitable to a diversity of opinions and aspirations. The Humphrey Institute does not itself take positions on issues of public policy. The contents of this report are the responsibility of its authors. 
it is now, the hidden closet for the skeletons of the rest of the system.

Patricia M. Wald January 1975

Each year more than 400,000 youth are admitted to state and local juvenile detention centers. In spite of these large numbers and the important role of detention in juvenile justice, very little is known about current detention policies and practices. In fact, this area has not been studied carefully for more than a decade. ${ }^{1}$ The purpose of this paper is to examine the recent trends in juvenile detention. We hope that the findings will prove useful in promoting the cost-effective, humane, equitable, and safe use of juvenile detention facilities.

\section{PURPOSE OF DETENTION}

Over the past 30 years, a number of public and private juvenile justice, criminal justice, and professional organizations have issued standards for juvenile justice. ${ }^{2}$ Although the recommendations of the groups have varied, they agree that secure detention should be used only as a last resort and only for those juveniles who have allegedly committed serious delinquent acts, posing a clear and substantial threat to others or to themselves. ${ }^{3}$ In addition, all these standard-setting groups recommend that written and objective criteria for detention be employed to determine who should be detained and under what circumstances. ${ }^{4}$

In 1967 the National Council on Crime and Delinquency (NCCD) published its Standards and Guides for the Detention of Children and Youth. These standards defined detention as the "temporary care of a child who has committed a delinquent act and requires secure custody in a physically restricting facility pending court disposition or the child's return to another jurisdiction or agency" (NCCD 1967:2). In 1973 the National Advisory

1 There has not been a national assessment of juvenile corrections since 1974, when Rosemary Sarri published Under Lock and Key: Juveniles in Jails and Detention.

2 See NCCD, Standards and Guides, 1961; U.S. Department of HEW, Legisla. tive Guide, 1969; National Institute for Juvenile Justice and Delinquency Prevention, Report to the Administrator on Standards for the Administration of Juvenile Justice: Standards on Adjudication, 1976; Institute of Judicial AdministrationAmerican Bar Association, Standards Relating to Interim Status, 1980; Commission on Accreditation for Corrections, American Correctional Association, Manual of Standards for Juvenile Detention Facilities and Services, 1979; National Advisory Committee for Juvenile Justice and Delinquency Prevention, Standards for the Administration of Juvenile Justice, 1980.

3 ACA, 1979, standard 8397; IJA-ABA, 1980, standard 3.2; NAC, 1980, standard 3.151; NIJJDP, 1976 p. 86.

4 ACA, 1979, standard 8393; IJA-ABA, 1980, standard 6.5, 7.1. 
Commission on Criminal Justice Standards and Goals recommended that "detention should be considered as a last resort where no other reasonable alternative is available" (NACCJSG 1973:259). The commission also stated that "detention should be used only where the juvenile has no parent, guardian, custodian, or other person to assure his (or her) presence at subsequent judicial hearings" (NACCJSG 1973:259).

In 1980 the National Advisory Committee for Juvenile Justice and Delinquency Prevention (NACJJDP) recommended that:

... a juvenile accused of a delinquent offense should be unconditionally released unless detention in a secure or nonsecure facility or imposition of conditions on release is necessary to protect the jurisdiction or process of the family court; to prevent the juvenile from inflicting serious bodily harm on others or committing a serious property offense prior to adjudication, disposition or appeal; or to protect the juvenile from imminent bodily harm (NACJJDP 1980:294).

During the same year, the Institute of Judicial Administration/ American Bar Association (IJA/ABA) promulgated its own standards. The IJA/ABA recommended that detention be restricted only to those juveniles who have committed the most serious offenses and that "detention not be imposed on an accused juvenile to punish, treat, or rehabilitate the juvenile" (IJA/ABA 1980:21).

Each of these juvenile justice standards calls for a judicial hearing on the decision to detain a juvenile within a specified period of time, usually 48 hours or less. 5 The NACJJDP, for example, recommended that a detention hearing "should be held within 24 hours after a juvenile has been taken into custody" (NACJJDP 1980:311).

\section{EXTENT OF DETENTION}

Since the 1960s a number of national and state surveys of detention have been conducted. These studies indicate that between 400,000 and 530,000 juveniles have been admitted annually to secure detention facilities throughout the United States. In 1965, NCCD estimated that 409,218 juveniles were admitted to juvenile detention facilities that year (Pappenfort and Young 1980:44). Poulin and his colleagues estimated that during the mid-1970s approximately 520,000 juveniles were admitted annually to detention centers in the United States. More recently, we reviewed data reporting that 416,610 juveniles were admitted to secure detention centers in 1982 (Krisberg, Schwartz, Litsky, Austin 1986:18).

5 IJA-ABA, 1977; NAC, 1980, standards, 3.151, 3.153, ACA, 1979, standards, 8395, 9397. 
Although large numbers of youth are admitted each year to detention centers, studies show large disparities in admissions rates and detention practices among the states (NCCD 1967: Poulin et al. 1980). One study found that admissions rates to secure detention in 1979 varied from a high of 5,685 per 100,000 eligible youth in Nevada to a low of 256 per 100,000 eligible youth in South Carolina (Krisberg and Schwartz 1983:346-47). In addition, states differ widely with respect to the average length of stay in detention; in 1979 the average length of stay ranged from three days in Arkansas to 33 days in South Carolina (Krisberg, Litsky, and Schwartz 1984:168). It also appears that in general, the western states detain juveniles at substantially higher rates than other regions of the country (Poulin et al. 1980).

\section{OVERUSE OF DETENTION}

Many issues related to juvenile detention continue to concern policymakers, juvenile justice professionals, and child advocates, but no issue has been of greater concern than the overuse of detention and its implications for policy, programs, and costs. Of the reported 409,218 juveniles detained in 1965, 41 percent were subsequently neither committed to an institution nor placed on probation (NCCD 1967:36). In 1967 the President's Commission on Law Enforcement and the Administration of Justice reported that onethird of those held in detention never appeared in court (Lerman 1977:390). Moreover, juveniles who commit status offenses (behavior that would not be illegal if committed by an adult) and juveniles accused of minor delinquent acts can still be found in many detention centers (Poulin et al. 1980). The IJA/ABA noted that the detention of juveniles before adjudication is:

... characterized by the very large numbers of juveniles incarcerated during this stage annually, the harsh conditions under which they are held, the high costs of such detention, and the harmful after-effects detention produces (IJA/ABA 1980:1).

A number of factors appear to play a significant role in the excessive and indiscriminate use of detention. One of these factors concerns the lack of adequate detention criteria. A 1980 survey of selected counties across the United States found that more than half of all juveniles detained would have been ineligible for secure detention on the basis of criteria recommended by the National Advisory Committee on Juvenile Justice and Delinquency Prevention (Kihm 1980:21). The survey also found that although state statutes outlining the criteria for pre-adjudication juvenile detention are becoming more specific, they are still too vague to be 
meaningful for day-to-day detention decisions (Kihm 1980; King 1980). The statutory vagueness allows for the exercise of broad discretion by police officers and detention center intake personnel. Even more alarming, the juvenile codes in as many as 17 states do not specify any criteria for initial detention decisions (King 1980). As recently as 1978, only 26 jurisdictions mandated detention hearings for detained juveniles (Shamburek 1978); even fewer required a hearing within the recommended 48-hour deadline (King 1980).

Other studies have shown that decisions to detain juveniles may be determined by (1) whether there is a detention center in the county (Pawlak 1977; Poulin et al. 1980), (2) whether alternative placements are available in the community (Pappenfort and Young 1980), (3) the time and location of apprehension (Sarri 1974 ), or (4) whether parents or guardians are willing to accept the juvenile back into their home (Blum 1978; Rubin 1980). These reasons for detention point to system-level deficiencies that cause excessive use of detention facilities.

The overuse of secure detention is of concern for a number of reasons. To begin with, some studies have found that detention decisions contribute to negative labeling of troubled youth. In their landmark ten-year study of the Massachusetts youth detention and correctional system, Harvard researchers found that preadjudication decisions regarding secure detention attach lasting labels to youths (Coates, Miller, and Ohlin 1978). The Harvard researchers, among others, found that this organizational labeling process has significant implications with respect to subsequent dispositions by the court and by others (Auby 1971; Coates, Miller, and Ohlin 1978; Pernell 1978). There is also concern that secure detention hampers the preparation of the juvenile's defense by limiting constructive contact between the juvenile and his or her attorney and witnesses (Shamburek 1978:542). Moreover, detention centers are generally highly secure facilities with only limited resources for treatment and education.

\section{DATA SOURCES}

The data for this study were derived from the Children in Custody (CIC) survey, a biennial census of children in public juvenile detention and correctional facilities. The census, begun in 1971 and administered by the United States Census Bureau, is a national survey of all publicly operated juvenile detention and correctional facilities. In addition, a special survey was conducted in 1974 to coincide with the implementation of the Juvenile Justice and Delinquency Prevention Act. The most recent survey was 
conducted in 1982. The CIC survey is designed to gather comprehensive and detailed information both about the facilities and about the youth who are admitted. The CIC survey form requests data from facility administrators on the number of youth admitted to the facilities, one-day census counts by age, sex, and race, and programmatic and budgetary information about the facilities.

One remarkable aspect of the CIC Data base is that the response rate has never been less than 96 percent. In 1979 and 1982 the survey drew a 100 percent response from the more than 1,000 facilities that were surveyed.

Although the data base is relatively comprehensive, it has some significant limitations. The annual admissions data do not represent an unduplicated count, nor is the survey instrument designed to collect admissions data by offense. In addition, the data in the CIC survey reflect only juveniles detained in juvenile facilities. Although a substantial number of juveniles are detained in adult jails, the CIC survey does not include this information. As a result, juveniles detained in adult jails were not considered in this study.

\section{DECLINING RATES OF ADMISSIONS TO DETENTION CENTERS}

In 1982 there were 390 juvenile detention centers in the United States. Virtually all of these (97\%) were classified as physically secure. These centers had a design capacity of 16,806 and an average daily population of 13,345 . The total staff complement was 12,621; their annual operating costs were \$313,584,242 (Krisberg, Austin, Melnicoe, Litsky, Claire, Trumm, Schwartz, Bermont, and Merriam 1984).

The CIC data also revealed that a significant number of detention centers were chronically overcrowded in 1982. In that year, 47 detention facilities had an average daily population that exceeded their design capacity. A substantial proportion of these facilities were located in Florida and California; 13 detention centers in Florida and seven in California were chronically overcrowded.

The CIC data indicate a steady decline in both the number and the rate of admissions to detention centers between 1977 and 1982. As Table 1 shows, the number of admissions declined by 73,084 , while the rate of admissions dropped from 1,686 per 100,000 eligible youth to 1,518 per 100,000 . In addition, the number and rate of admissions declined for both sexes, although the decline was greater for females than for males.

Researchers who examined detention practices in different states consistently find large disparities between admission rates 
Table 1. United States public juvenile detention centers: numbers of admissions and admissions rates by sex, 1977-1982.*

Total Rate Per Male Rate Per Female Rate Per Admissions 100,000 Admissions 100,000 Admissions 100,000

\begin{tabular}{rrrrrrr}
\hline 1977 & 489,694 & 1,686 & 375,728 & 2,658 & 113,966 & 765 \\
1979 & 451,810 & 1,573 & 356,167 & 2,548 & 95,643 & 649 \\
1982 & 416,610 & 1,518 & 330,075 & 2,473 & 86,535 & 614 \\
\hline
\end{tabular}

Rates based on eligible youth population age 10 through age of juvenile court jurisdiction for each state and the District of Columbia.

Source: U.S. Census Bureau, Children in Custody Series

among states (Sarri 1974; Poulin et al. 1980; Krisberg, Litsky, and Schwartz 1984). Krisberg and his colleagues used a limited number of variables to explore some of the possible reasons for the disparities reflected in the 1979 CIC survey. Using stepwise multiple regression techniques, they found that the admissions rates were largely unrelated to a state's Part I property or violent juvenile crime rate, but they did find a significant relationship between admissions rates and the availability of beds (Krisberg, Litsky, and Schwartz 1984:159-62).

Although the 1982 CIC data indicate that this disparity continues, the data also suggest that rates of detention admissions in individual states may fluctuate widely from year to year. Table 2 shows that between 1977 and 1982, detention admissions rates declined in 28 states and increased in 17 states. The detention admissions rates in a number of states, however, do not reflect a consistent upward or downward trend.

\section{INCREASING ONE-DAY COUNTS OF YOUTH IN DETENTION}

While the number of admissions has been dropping, the number of youth in one-day counts of detention center residents has increased. Between 1977 and 1982, the number of residents increased by 1,811 or almost 19 percent. During the same period, admissions declined by 15 percent. This apparent anomaly of rising populations and declining admissions is explained by large increases in the average length of stay of detained youth. From 1977 to 1982 , the average stay in detention centers rose from 12 days to 17 days. The major reason for the increasing stays involves the growing judicial practice of committing adjudicated youth to detention centers as part of their court dispositions. A short stay in detention is usually tacked onto a sentence to probation.

As Table 3 shows, the number of juveniles committed (or sentenced) to detention centers has increased substantially. In 1977, 
Table 2. United States public juvenile detention centers: admissions rates by state, 1977-1982.*

\begin{tabular}{|c|c|c|c|c|}
\hline & & $\begin{array}{c}1977 \\
\text { Admission } \\
\text { Rate } \\
\end{array}$ & $\begin{array}{c}1979 \\
\text { Admission } \\
\text { Rate } \\
\end{array}$ & $\begin{array}{c}1982 \\
\text { Admission } \\
\text { Rate } \\
\end{array}$ \\
\hline 1. & Alabama & 836 & 790 & 570 \\
\hline 2. & Alaska & 313 & 350 & 1,241 \\
\hline 3. & Arizona & 3,079 & 2,826 & 2,134 \\
\hline 4. & Arkansas & 616 & 1,186 & 406 \\
\hline 5. & California & 4,838 & 4,393 & 3,608 \\
\hline 6. & Colorado & 2,291 & 2,572 & 2,426 \\
\hline 7. & Connecticut & 581 & 745 & 520 \\
\hline 8. & Delaware & 1,924 & 1,415 & 1,192 \\
\hline 9. & District of Columbia & 4,743 & 3,384 & 4,207 \\
\hline 10. & Florida & 2,589 & 2,480 & 2,721 \\
\hline 11. & Georgia & 1,982 & 2,078 & 2,112 \\
\hline 12. & Hawaii & 1,689 & 1,816 & 1,964 \\
\hline 13. & Idaho & 570 & 1,617 & 1,005 \\
\hline 14. & Illinois & 950 & 871 & 1,314 \\
\hline 15. & Indiana & 1,101 & 1,184 & 1,321 \\
\hline 16. & Iowa & 333 & 313 & 568 \\
\hline 17. & Kansas & 1,140 & 1,199 & 929 \\
\hline 18. & Kentucky & 1,482 & 750 & 592 \\
\hline 19. & Louisiana & 812 & 700 & 752 \\
\hline 20. & Maine & - & - & - \\
\hline 21. & Maryland & 482 & 542 & 608 \\
\hline 22. & Massachusetts & 823 & 526 & 827 \\
\hline 23. & Michigan & 1,254 & 1,295 & 1,040 \\
\hline 24. & Minnesota & 970 & 1,019 & 951 \\
\hline 25. & Mississippi & 725 & 686 & 1,044 \\
\hline 26. & Missouri & 1,818 & 1,741 & 1,613 \\
\hline 27. & Montana & - & - & - \\
\hline 28. & Nebraska & 859 & 763 & 932 \\
\hline 29. & Nevada & 6,280 & 5,685 & 6,322 \\
\hline 30. & New Hampshire & $\therefore$ & - & - \\
\hline 31. & New Jersey & 954 & 1,001 & 998 \\
\hline 32. & New Mexico & 3,307 & 1,969 & 2,755 \\
\hline 33. & New York & 592 & 455 & 389 \\
\hline 34. & North Carolina & 525 & 556 & 451 \\
\hline 35. & North Dakota & 398 & 598 & 482 \\
\hline 36. & Ohio & 1,883 & 2,039 & 2,091 \\
\hline 37. & Oklahoma & 604 & 642 & 636 \\
\hline 38. & Oregon & 2,226 & 2,116 & 2,224 \\
\hline 39. & Pennsylvania & 916 & 925 & 836 \\
\hline 40. & Rhode Island & - & - & - \\
\hline 41. & South Carolina & 233 & 256 & 314 \\
\hline 42. & South Dakota & 1,239 & 1,260 & 1,643 \\
\hline 43. & Tennessee & 2,527 & 2,100 & 1,958 \\
\hline 44. & Texas & 1,369 & 1,271 & 1,207 \\
\hline 45. & Utah & 2,815 & 2,525 & 3,011 \\
\hline 46. & Vermont & - & - & \\
\hline 47. & Virginia & 1,649 & 1,626 & 1,594 \\
\hline 48. & Washington & 4,803 & 3,420 & 4,172 \\
\hline 49. & West Virginia & 441 & 473 & 314 \\
\hline 50. & Wisconsin & 726 & 371 & 525 \\
\hline 51. & Wyoming & - & - & - \\
\hline
\end{tabular}


Table 3. United States public jurenile detention centers: total detention admissions and commitments to detention, 1977-1982.

\begin{tabular}{lrrr}
\hline & 1977 & 1979 & 1982 \\
\hline Male & & & \\
Total Admissions & 375,728 & 356,167 & 330,075 \\
Commitments & 3,806 & 11,262 & 17,466 \\
Female & & & \\
Total Admissions & 113,966 & 95,643 & 86,535 \\
Commitments & 998 & 2,061 & 3,561 \\
\hline TOTALS & & & \\
Admissions & 489,694 & 451,860 & 416,610 \\
Commitments & 4,804 & 13,863 & 21,027 \\
\hline
\end{tabular}

Source: U.S. Census Bureau, Children in Custody Series.

4,804 juveniles were committed to detention centers; by 1982 that number had increased to 21,027 .

The increase in the number of juveniles sentenced to detention centers appears to be exerting a significant effect on the centers. Table 4 shows that the total number of detention days increased by 483,669 between 1977 and 1982 . Committed youth accounted for more than 80 percent of the increase in detention days. This large increase in detention days is due both to the increase in the number of these types of admissions and to the difference in the average length of stay: committed youths are detained nearly $21 / 2$ times as long as pre-adjudicated detainees.

The practice of committing juveniles to secure detention centers is gaining in popularity and spreading rapidly throughout the country. As Table 5 shows, the number of states where detention center sentences were recorded more than doubled between 1977 and 1982. In addition, states differ greatly in the extent of detention center commitments and the average length of stay of these sentences. ${ }^{6}$ In 1982 the average stay ranged from three days in Utah to 304 days in North Carolina. The national average length of stay for committed youth in detention centers was approximately 28 days. However, California alone accounted for approximately one-half of the juveniles committed to detention in the United States and over one-half of the total detention days of committed youth.

6 The disparities between states are also evident in the diversity of practices regarding the preadjudicated detention population. For example, the national average length of stay for juveniles confined on a pre-adjudication basis was 11.5 days in 1982 , but the average length of stay ranged from one day in the District of Columbia to 27 days in Alabama. 
Table 4. United States public juvenile detention centers: average length of stay and detention days by admissions status, 1977-1982.

\begin{tabular}{|c|c|c|c|c|c|}
\hline Year & $\begin{array}{l}\text { Committe } \\
\text { Average } \\
\text { Length } \\
\text { of Stay }\end{array}$ & Juveniles & $\begin{array}{c}\text { Preadjudica } \\
\text { Length } \\
\text { of Stay }\end{array}$ & Total Days & $\begin{array}{l}\text { All Juveniles } \\
\text { Total Days of } \\
\text { Detention for } \\
\text { Committed, } \\
\text { Preadjudicated, } \\
\text { and Other } \\
\text { Admissions* }\end{array}$ \\
\hline $\begin{array}{l}1977 \\
1979 \\
1982\end{array}$ & $\begin{array}{l}35.81 \\
24.48 \\
27.62\end{array}$ & $\begin{array}{l}172,013 \\
326,203 \\
580,695\end{array}$ & $\begin{array}{r}9.23 \\
10.09 \\
11.50\end{array}$ & $\begin{array}{l}4,472,968 \\
4,416,457 \\
4,548,097\end{array}$ & $\begin{array}{l}4,646,466 \\
4,744,488 \\
5,130,135\end{array}$ \\
\hline
\end{tabular}

* Each year a relatively small number of juveniles are confined in detention centers on an "other" status. They are generally juveniles held for probation violations, who are behavior problems in shelter facilities or other nonsecuro placements.

Source: U.S. Census Bureau, Children in Custody Series.

Many juvenile justice professionals acknowledge that in some jurisdictions juveniles have been committed to detention centers on a limited and informal basis for years. The picture is changing, however, as evidence accumulates to suggest that in many jurisdictions juveniles are increasingly being committed as a result of formal policy. Lawmakers in Alaska, Colorado, Idaho, Washington, Illinois, Louisiana, New Mexico, New Jersey, North Carolina, and Virginia have recently enacted legislation allowing juveniles to be committed to detention. ${ }^{7}$ The Idaho statute dates back to 1963; the other states have passed special legislation authorizing these commitments since 1979.8

\section{DETENTION CENTERS AND MINORITY YOUTH}

The CIC data indicate a substantial increase in the number and proportion of minority youth confined in detention centers. As Table 6 shows, the number of juveniles found in detention centers in one-day counts declined slightly between 1977 and 1979, but the number increased substantially between 1979 and 1982 . The data makes it clear that virtually the entire increase was due to an increase in the number of minority youth being confined. This increase reflects a significant change in the racial attributes of

7 Alaska Stat. ss 47.10 .080 (1985); Colo. Rev. Stat. ss 19-8-117 (1985); Idaho Code ss 16-1836 (1985); Wash. Rev. Code Ann. ss 13.40.020 (1985); Ill. Rev. Stat. ch. 37 ss 705-2 (1985); La. Code Juv. Proc. ch. 16 Art. 83 (1985); N.M. Stat. Ann. ss 32-134 (1985); N.J. Stat. Ann. ss 2A:4A:43 (West, 1985); N.C. ss 7A-649 (1985); Va. Code ss 16.1-279 (Supp. 1985).

8 See 1981 Colorado Session Law, ch. 236; 1979 Illinois Laws, Pub. Act 81-930; 1984 Louisiana Acts, Act 567; 1982 N.J. Laws ch. 77 ss 24; 1981 N.M. Laws, ch. 36; 1985, Virginia Acts, ch. 260. 


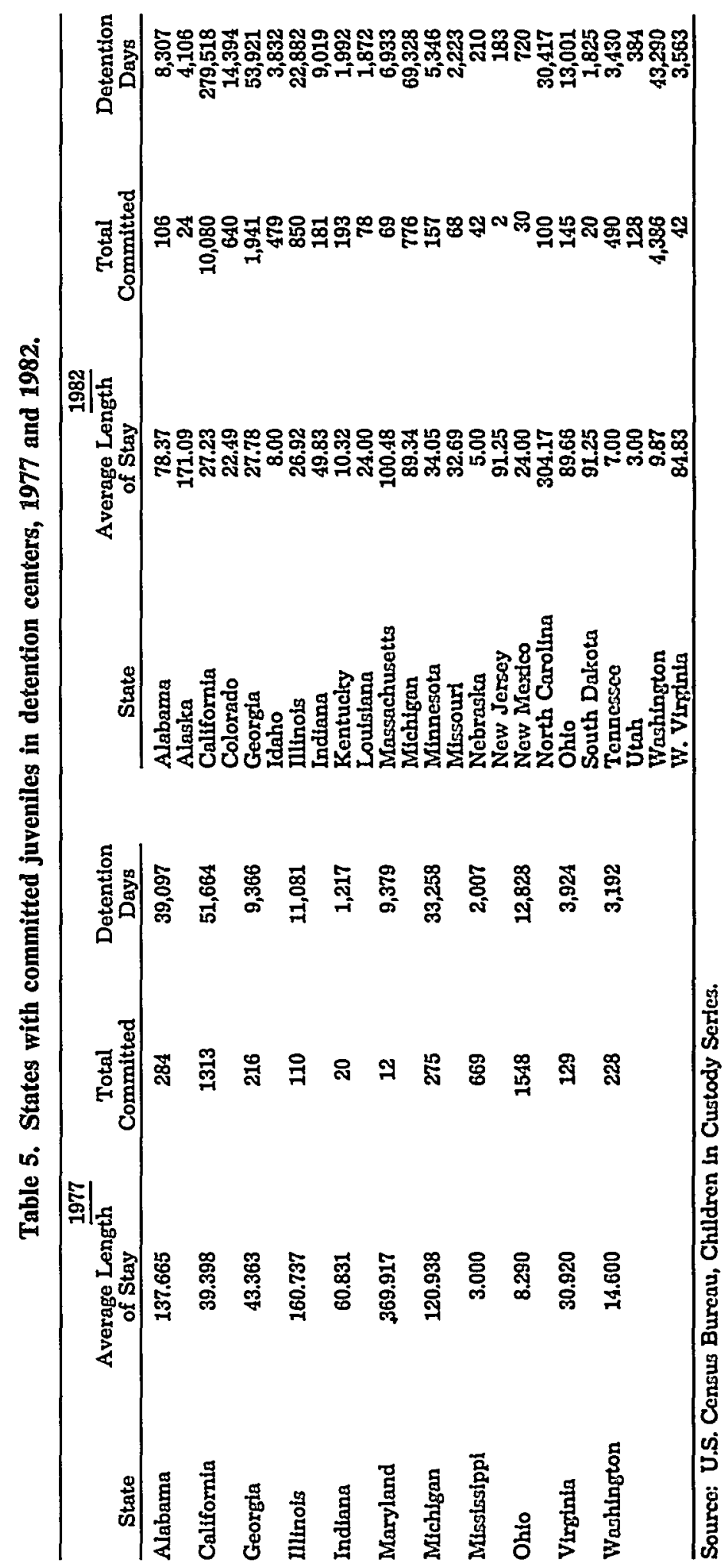




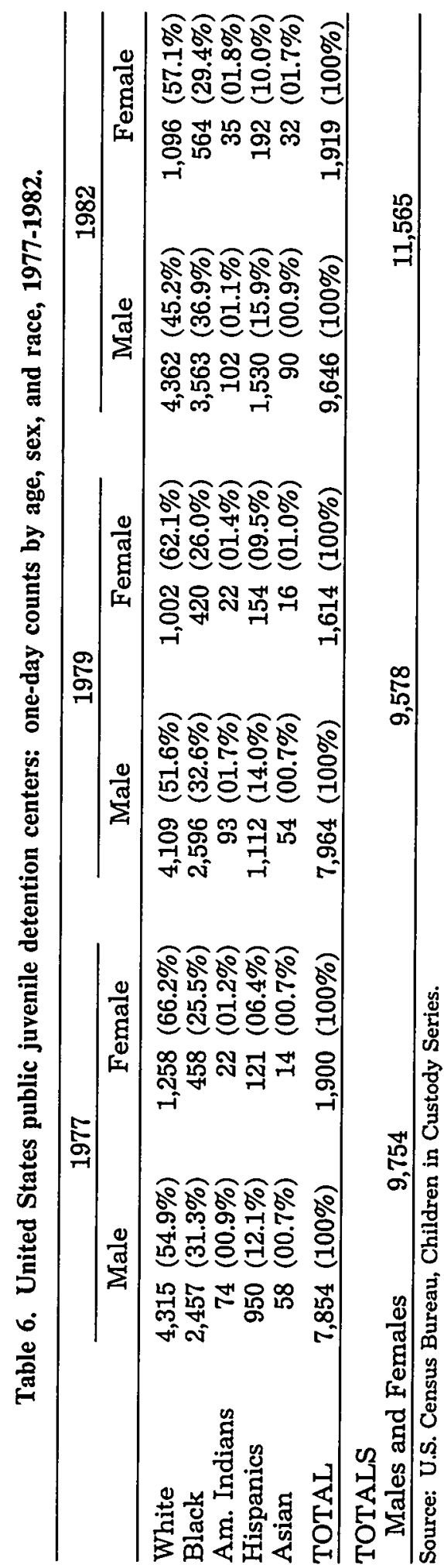


juveniles confined in public detention centers. Black and Hispanic youth now constitute over 50 percent of these juveniles.

These findings are similar to those reported in a recent study, "The Incarceration of Minority Youth." The authors of that study, which examines this subject in detail, raise a number of other major concerns. They found, for example, ". . . that minority youth are incarcerated at a rate three to four times that of whites" (Krisberg, Schwartz, Fishman, Eisikovits, and Guttman 1986:29-30), but that the higher rate of incarceration for minorities did not prove to be ". . . a function of their greater involvement in serious criminal behavior" (Krisberg et al. 1986:30).

\section{POLICY CONSIDERATIONS AND RECOMMENDATIONS}

The findings of this study raise a number of issues that should be of concern to policy makers, juvenile justice professionals, and child advocates. These include the following:

\section{Short-term Commitments}

There has been a steady decline in both the number and the rate of admissions to juvenile detention centers throughout the country. Yet despite declining admissions, the total number of detention days has increased substantially, largely because of the growing trend toward committing (or sentencing) youth to detention facilities. There is evidence that this practice occurs increasingly as a result of formal policy; lawmakers in a number of states have enacted legislation allowing commitment to detention to take place. The best available evidence suggest that this trend will continue.

Many juvenile court judges and probation officials strongly support detention commitments. They maintain that short-term commitment programs are needed for juveniles who violate court orders or fail to adhere to the conditions of probation. Further, juvenile court officials maintain that detention serves as an alternative to training schools. They argue that detention centers are located "in the community," so that committed juveniles can be kept "close to family and friends."

On the surface these arguments appear to hold some merit, but certain important child-welfare and public-policy implications must be considered. Committing juveniles to detention centers represents a major and fundamental change in the use of these facilities. Until now, professionals have agreed that secure detention centers should be reserved for juveniles who need to be confined pending the disposition of their juvenile court cases. This thinking has been reinforced by the recommendations of virtually all 
groups who set juvenile justice standards and by the professional literature. Accordingly, juvenile detention centers are built, staffed, and programmed for the single purpose of highly secure short-term confinement.

Juvenile court judges may need increased short-term commitment options, but in many jurisdictions the practical effect of committing juveniles to detention centers is that juveniles who are accused of committing very serious crimes and are awaiting court hearings are being commingled with youth who have been adjudicated for relatively minor delinquent behavior. Very few detention centers are designed to house these two populations separately or to provide individual treatment and educational programs.

Juveniles confined for pre-adjudication are presumed innocent and are generally entitled to more rights than are committed youth. Experts in juvenile law maintain that pre-adjudicated youth cannot be confined under conditions that would amount to punishment. They also maintain that these juveniles have a right to be protected from harm; that is, they should be kept separate from serious and violent offenders. On the other hand, many juvenile statutes proclaim that one of the main purposes of commitment is treatment and rehabilitation (Horowitz and Davidson 1984:498). With relatively few exceptions, the programs in detention facilities fall far short of this standard.

Committing juveniles to detention centers is a costly practice. If we assume a conservative per diem detention expenditure of $\$ 75$, the cost for the 580,695 days of detention accumulated by committed youth in 1982 amounted to approximately $\$ 43$ million. On the basis of the figures for an average length of stay, the cost for each juvenile committed to a detention facility was greater than $\$ 2,000$.

\section{Excessive Use of Detention}

The excessive use of detention continues to be a problem in many jurisdictions. A recent study in Colorado reported that approximately 50 percent of all juveniles admitted to detention were released within 48 hours or less (Department of Institutions, Division of Youth Services 1986:48). If the great majority of juveniles admitted to detention represented an immediate and substantial threat to community safety, or if these youths had proved previously not to be amenable to less secure options, relatively few of them would have been released so quickly. 
A study in Ohio concluded that detention center populations could be reduced significantly though the use of expansion of existing home detention programs (Huff 1986:32).

Because of the high costs and adverse consequences of overusing detention, policymakers and practitioners should make every effort to restrict admissions to those juveniles who absolutely require confinement. To accomplish this objective, authorities should consider (1) using the criteria for admission promulgated by the National Advisory Committee for Juvenile Justice and Delinquency Prevention, and (2) replicating the procedures currently used in jurisdictions with relatively low rates of admissions. In Genesee County, Michigan, for example, pre-adjudicatory detention has been reduced to the absolute minimum without sacrificing public safety. In 1985 only 282 juveniles were detained in this county, which has a population of 450,000 and includes the highly industrialized city of Flint. A recent study of the detention practices in Genessee County indicates that re-arrest rates and rates of failure to appear in court are relatively low (Thome et al. 1985).

\section{Minority Youth}

Since 1979 there has been a sharp increase in the number and proportion of minority youth confined in secure detention centers. Minority youth now account for more than 50 percent of all juveniles detained on a given day. This situation deserves the attention of juvenile justice researchers; many questions about law enforcement and detention practices are raised by the possibility that minority overrepresentation in detention centers does not seem to be a function of greater minority involvement in serious juvenile crime. As policymakers and juvenile justice professionals consider options for minimizing the use of detention, they should give particular attention to strategies that reduce the detention of minorities. Organizations concerned with minority youth, for example, should become involved in examining the detention issue and developing alternative programs.

\section{Overcrowding}

In 1982, 12 percent of the juvenile detention centers in the United States were chronically overcrowded. It is generally acknowledged that overcrowding is a major cause of warehousing, disciplinary problems, tensions among staff members, low staff morale, and violence among juveniles and between juveniles and staff. Unless current detention practices are reformed, many facilities will suffer even greater overcrowding in the next seven to ten years as the "echo baby boomers" pass through their high-risk 
years. In jurisdictions where overcrowding is a major problem or appears likely to be so in the near future, policymakers and juvenile justice professionals should study their detention populations immediately and determine what potential remedies may be available.

Juvenile detention policies and practices are undergoing significant and potentially fundamental changes. In particular, secure juvenile detention centers are beginning to fulfill a new role as short-term prisons for youth. This shift defies virtually all juvenile justice standards as well as the consensus of professional opinion. These developments suggest that juvenile detention deserves much more public attention; we should not tolerate the perpetuation of detention centers as the "hidden closets" that conceal the failure of family, school, church, and other social institutions.

\section{REFERENCES}

Aubry, E.L. (1971) "The Nature, Scope and Significance of Pretrial Detention of Juveniles in California." Black Lawo Journal 2: 160-70.

Blum, L. (1978) "Criminals Without Crime: The Dilemma of the Status Offender." Pepperdine Law Review 5(3): 695-715.

Coates, R.B., A.D. Miller, and L.E. Ohlin (1978) Diversity in a Youth Correctional System: Handling Delinquents in Massachusetts. Cambridge, MA: Ballinger.

Commission on Accreditation for Corrections. American Correctional Association (1979) Manual of Standards for Juvenile Detention Facilities and Services. Rockville, MD: Author.

The Institute of Judicial Administration and the American Bar Association Juvenile Justice Standards Project (1980) Standards Relating to Interim Status: The Release, Control, and Detention of Accused Juvenile Offenders Between Arrest and Disposition. Cambridge, MA: Ballinger.

Horowitz, R.M. and H.A. Davidson (1984) Legal Rights of Children. Colorado Springs, CO: McGraw-Hill.

Huff, C.R. (1986) Home Detention As a Policy Alternative for Ohio's Juvenile Courts. A Final Report to the Governor's Office of Criminal Justice Services. (Grant 84-JJ-C08-0712). Columbus, OH: Program for the Study of Crime and Delinquency, Ohio State University.

Kihm, R.C. (1980) Prohibiting Secure Juvenile Detention: Assessing the Effectiveness of National Standard Detention Criteria. Washington, DC: U.S. Department of Justice.

King, J.L. (1980) A Comparative Analysis of Juvenile Codes. Washington, DC: U.S. Government Printing Office.

Krisberg, B. and I. Schwartz (1983) "Rethinking Juvenile Justice." Crime and De. linquency 29(3): 333-64.

Krisberg, B., P. Litsky, and I. Schwartz (1984) "Youth in Confinement: Justice by Geography." Journal of Research in Crime and Delinquency 21(2): 153-81.

Krisberg, B., J. Austin, S. Melnicoe, P. Litsky, S. Claire, B. Trumm, I. Schwartz, J. Bermont and K. Merriam (1984) Rethinking Juvenile Justice: National Statistical Trends. Minnesapolis, MN: Hubert H. Humphrey Institute of Public Affairs.

Krisberg, B. I. Schwartz, P. Litsky, and J. Austin (1986) "The Watershed of Juvenile Justice Reform." Crime and Delinquency 32(1): 3-38.

Krisberg, B., I. Schwartz, G. Fishman, Z. Eisikovits, and E. Guttman (in press) "The Incarceration of Minority Youth." Crime and Delinquency. 
Lerman, P. (1977) "Delinquency and Social Policy: A Historical Perspective." Crime and Delinquency 23(4): 383-93.

National Advisory Committee for Juvenile Justice and Delinquency Prevention (1980) Standards for the Administration of Juvenile Justice. Washington, DC: U.S. Government Printing Office.

National Council on Crime and Delinquency (1961) Standands and Guides for the Detention of Children and Youth. New York: Author.

National Council on Crime and Delinquency (1967) "Corrections in the United States." Journal of Research in Crime and Delinquency 13(1): 9-38.

National Institute for Juvenile Justice and Delinquency Prevention (1977) Report of the Advisory Committee to the Administrator on Standards for the Administration of Juvenile Justice: Standards on Adjudication. Washington, DC: Law Enforcement Assistance Administration.

Pappenfort, D.M. and T.M. Young (1980) "Use of Secure Detention for Juveniles and Alternatives to Its Use." Reports of the National Juvenile Justice Assessment Centers. Washington, DC: U.S. Department of Justice.

Pawlak, E.J. (1977) "Differential Selection of Juveniles for Detention." Journal of Research in Crime and Delinguency 14(2): 152-65.

Pernell, L. (1978) "Interim Detention of Juvenile Delinquents in Ohio: A Proposal for Controlling Judicial Discretion." Ohio State Law Revievo 39(2): 306-26.

Poulin, J.E., J.L. Levitt, T.M. Young, and D.M. Pappenfort (1980) Reports of the National Juvenile Justice Assessment Centers. Juveniles in Detention Centers and Jails: An Analysis of State Variations During the Mid 1970's. Washington DC: U.S. Government Printing Office.

Rubin, H.T. (1980) Juveniles in Justice, A Book of Readings. Santa Monica, CA: Goodyear.

Sarri, R.C. (1974) Under Lock and Key: Juveniles in Jails and Detention. Ann Arbor, MI: The University of Michigan.

Shamburek, P.A. (1978) "Due Process Dliemma: Pretrial Detention in Juvenile Delinquency Proceedings." John Marshall Journal of Practice and Procedure 11(3): $513-47$.

Springer, K. (1986, January 5) "Youth Crime, Detentions on the Rise." The SunSentinel, Ft. Lauderdale, FL.

Thome, J.E., T. Bynum, K.W. Welch, G. Ghalhammer (1985) Juvenile Detention Decisions in Genesse County Michigan. (U.S. Dept. of Justice Contract No. JLEAA-012-81). Champaign, IL: Community Research Center, University of Illinois at Urbana-Champaign.

U.S. Department of Health, Education and Welfare (1969) Legislative Guide for Drafting Family and Juvenile Court Acts. Washington, DC: Author. 
HeinOnline -- 4 Just. Q. 2361987 